\title{
PENGARUH STRATEGI HEURISTIK VEE TERHADAP KEMAMPUAN PEMAHAMAN KONSEP MATEMATIK
}

\author{
Otong Suhyanto ${ }^{1)}$ dan Eva Musyrifah²) \\ UIN Syarif Hidayatullah Jakarta \\ 1) otong.suhyanti@uinjkt.ac.id \\ 2) eva.musyrifah@uinjkt.ac.id
}

\begin{abstract}
Abstrak
Tujuan penelitian ini adalah untuk mengetahui pengaruh strategi pembelajaran heuristik vee terhadap kemampuan pemahaman konsep matematik. Penelitian ini dilakukan pada Jurusan Pendidikan Matematika, Fakultas Ilmu Tarbiyah dan Keguruan, Universitas Islam Negeri Syarif Hidayatullah Jakarta Semester V tahun akademik 2015/2016 dengan desain randomized control group post test only design. Subyek penelitian ini adalah 55 mahasiswa yang terdiri dari 28 mahasiswa kelompok eksperimen dan 27 mahasiswa kelompok kontrol yang diperoleh dengan teknik cluster random sampling. Kemampuan pemahaman konsep matematik mahasiswa dikumpulkan dengan menggunakan tes essay. Hasil penelitian mengungkapkan bahwa kemampuan pemahaman konsep matematik mahasiswa yang diajar dengan strategi pembelajaran heuristik vee lebih tinggi dari pada kemampuan pemahaman konsep matematika mahasiswa yang diajar dengan strategi pembelajaran konvensional. Hal ini dapat dilihat dari nilai rata-rata hasil tes kemampuan pemahaman konsep matematik mahasiswa yang diajar dengan strategi pembelajaran heuristik vee sebesar 83,96 dan nilai rata-rata hasil tes kemampuan pemahaman konsep matematik mahasiswa yang diajar dengan strategi pembelajaran konvensional sebesar 78,3. Berdasarkan hasil uji beda rata-rata diperoleh $\left(t_{\text {hitung }}=1,92\right.$ dan $t_{\text {tabel }}=$ 1,66), karena $t_{\text {hit }}<t_{\text {tab }}$ maka $H_{0}$ ditolak dan $H_{1}$ diterima. Kesimpulan hasil penelitian ini adalah bahwa pembelajaran pada Matakuliah Persamaan Diferensial dengan menggunakan strategi pembelajaran heuristicvee berpengaruh terhadap kemampuan pemahaman konsepmatematik mahasiswa.
\end{abstract}

Key Word: Heuristicvee, Pemahaman Konsep Matematika Mahasiswa.

\section{PENDAHULUAN}

Pendidikan merupakan salah satu hal penting untuk menentukan maju mundurnya suatu bangsa, sehingga peranannya sangat sentral dalam meningkatkan sumber daya manusia. Pendidikan akan membantu mahasiswa dalam mengembangkan aspek kognitif, afektif, psikomotor. Oleh karena itu, penting bagi dosen untuk mengetahui kemampuan yang telah 
dimiliki peserta didik dan kesulitan-kesulitan mereka selama proses pembelajaran berlangsung.

Sebagian dosen matematika memulai proses pembelajaran dengan membahas pengertiannya/definisi, lalu memberikan contoh-contoh diikuti dengan mengumumkan aturanaturannya kemudian meminta para mahasiswa untuk mengerjakan soal-soal latihan. Selain itu dosen juga sering lupa memberikan keterkaitan antara konsep yang dipelajari mahasiswa dalam matematika itu sendiri, maupun dengan kehidupan sehari-hari. Contoh soal yang sering diberikan biasanya hanya soal yang kategorinya sangat mudah, jarang sekali berbentuk soal cerita yang menuntut pemahaman konsep.

Pembelajaran matematika di sekolah seharusnya dapat membekali peserta didik dengan kemampuan bernalar, pemahaman, komunikasi, berpikir logis, kritis, dan kreatif. Pada Standar Isi Mata Pelajaran Matematika untuk semua jenjang pendidikan dasar dan menengah dinyatakan bahwa tujuan mata pelajaran matematika di sekolah adalah agar mahasiswa mampu (Wardhani, 2008):

1. Memahami konsep matematika, menjelaskan keterkaitan antarkonsep dan mengaplikasikan konsep atau algoritma, luwes, akurat, efisien, dan tepat dalam pemecahan masalah,

2. Memiliki sikap menghargai kegunaan matematika dalam kehidupan, yaitu memiliki rasa ingin tahu, perhatian, dan minat dalam mempelajari matematika, serta sikap ulet dan percaya diri dalam pemecahan masalah.

Kesulitan belajar matematika yang dialami mahasiswa berhubungan dengan kemampuan belajar yang kurang sempurna serta mahasiswa menganggap konsep sebelumnya tidak akan digunakan lagi sehingga terdapat kesenjangan antara apa yang dikehendaki dengan apa yang terjadi di lapangan. Kekurangan tersebut dapat terungkap dari penyelesaian persoalan matematika yang tidak tuntas. Ketidaktuntasan tersebut dapat diduga karena kesalahan penggunaan konsep dan prinsip dalam menyelesaikan persoalan matematika yang diperlukan. Konsep dan prinsip matematika dapat pula dihubungkan pada kemampuan mahasiswa tersebut dari segi pemahaman konsep matematikanya.

Aktivitas di kelas masih tergolong pasif yang mengakibatkan peserta didik tidak bisa bereksplorasi dalam artian tidak bisa menggali pengetahuan sendiri. Hal tersebut berdampak pada pengetahuan yang dimiliki peserta didik tidak bersifat "long term memory" sehingga tidak jarang ada peserta didik yang sudah melupakan pembelajaran dengan begitu cepat karena konsep yang dimiliki hanya bersifat hafalan, bukan pemahaman. Otak anak dipaksa untuk mengingat dan menimbun berbagai informasi tanpa dituntut untuk memahami 
informasi yang diperoleh tersebut. Kemampuan peserta didik dalam memahami pelajaran matematika pada saat proses pembelajaran masih rendah disebabkan mahasiswa sering lupa materi-materi yang sudah diajarkan sebelumnya yang merupakan prasyarat yang harus dikuasai.

Berdasarkan penelitian Calais (Gerald J. Calais, 2009) dalam penelitiannya yang berjudul "the vee diagram as a problem solving strategy: content area reading/writing implication". Hasil penelitiannya menunjukkan bahwa diagram vee (sebuah pembelajaran heuristik) adalah strategi yang ideal untuk meningkatkan kemampuan penemuan siswa dalam penyelidikan sains dan matematika.

Berdasarkan uraian sebelumnya maka perumusan masalah dalam penelitian ini: Apakah kemampuan pemahaman konsep matematik mahasiswa yang diajarkan denganmenggunakan strategi pembelajaran heuristik vee lebih tinggi dari mahasiswayang diajarkan dengan menggunakan strategi pembelajaran konvensional?

Tujuan dari penelitian ini adalah untuk:

a. Mengetahui kemampuan pemahaman konsep matematik mahasiswa yang diajarkan denganstrategi pembelajaran heuristik vee dengan konvensional.

b. Untuk mengetahui apakah kemampuan pemahaman konsep matematik mahasiswa yangdiajarkan dengan menggunakan strategi pembelajaran heuristik vee lebih tinggi dari mahasiswa yang diajarkan dengan menggunakan strategi pembelajaran konvensional.

\section{Kemampuan Pemahaman Konsep Matematik}

Pemahaman konsep menurut Gagne yang dikutip oleh Suherman konsep adalah ide abstrak yang memungkinkan kita dapat mengelompokan objek ke dalam contoh dan non contoh. Sedangkan Suherman menyatakan bahwa konsep adalah kumpulan fakta spesifik yang saling terkait secara fungsiona (Suherman, 2003). Rooser (dalam Ratna Wilis Dahar, 2006) juga mengemukakan bahwa konsep adalah suatu abstraksi yang mewakili satu kelas objek-objek, kejadian-kejadian, kegiatan-kegiatan, atau hubungan yang mempunyai atribut yang sama.

Menurut Rosyada pemahaman adalah comprehension yaitu kemampuan untuk memahami apa yang sedang dikomunikasikan dan mampu mengimplementasikan ide tanpa harus melihat ide itu secara mendalam (Rosyada. 2004). Pemahaman bukan hanya sekedar mengingat fakta, akan tetapi berkenaan dengan kemampuan menjelaskan, menerangkan, menafsirkan, atau kemampuan menangkap makna atau arti suatu konsep. Seseorang dikatakan memahami sesuatu jika telah dapat mengungkapkan kembali apa yang dipelajarinya dengan 
menggunakan kalimatnya sendiri, termasuk di dalamnya menafsirkan suatu bagan, gambar, grafik untuk menjelaskan dengan kalimatnya sendiri dengan tidak lagi mengingat atau menghafal informasi yang diperolehnya.

Kilpatrick dan Findell menyebutkan bahwa pemahaman konsep berkenaan dengan memahami ide-ide matematika yang menyeluruh dan fungsional. Mahasiswa yang memiliki pemahaman konsep lebih mengetahui fakta dan metode yang terpisah. Mereka mengerti mengapa ide-ide matematika penting dan macam-macam hubungan kalimat yang berguna. Selanjutnya Kilpatrick dan Findell mengemukakan indikator pemahaman konsep, yaitu (Kilpatrick, J., Swafford, J., \& Findell, 2001):

a. Kemampuan menyatakan ulang konsep yang telah dipelajari.

b. Kemampuan mengklasifikasikan objek-objek berdasarkan sifat-sifat tertentu sesuai dengan konsepnya.

c. Kemampuan menerapkan konsep secara algoritma.

d. Kemampuan memberikan contoh dannon contoh dari konsep yang telah dipelajari.

e. Kemampuan menyajikan konsep dalam berbagai macam bentuk representasi matematika.

f. Kemampuan mengaitkan berbagai konsep (internal dan eksternal matematika)

g. Kemampuan mengembangkan syarat perlu dan syarat cukup suatu konsep.

Sedangkan pemahaman konsep menurut Skemp terbagi atas tiga bagian pemahaman, yaitu pemahaman instrumental, pemahaman relasional, dan pemahaman logis.Pemahaman instrumental diartikan sebagai pemahaman atas konsep yang saling terpisah dan hanya hafal rumus dalam perhitungan sederhana. Pemahaman relasional termuat skema atau struktur yang dapat digunakan pada penyelesaian yang lebih luas dan sifat pemakaiannya lebih bermakna. Mahasiswa yang telah memiliki pemahaman relasional dan mengaitkan suatu konsep lainnya secara benar dan menyadari proses yang dilakukan. Dan Pemahaman logis merupakan kemampuan untuk meyakinkan orang lain dalam memberikan solusi suatu masalah. Jadi dalam pemahaman ini mahasiswa dapat mengetahui bagaimana menyelesaikannya lalu menjelaskan prosedurnya dan meyakinkan orang lain dengan argumentasi yang logis.

Berdasarkan uraian sebelumnya dapat dikemukakan bahwa pemahaman konsep matematika adalah kemampuan mahasiswa dalam menerjemahkan, menafsirkan, dan menyimpulkan suatu konsep matematika berdasarkan pembentukan pengetahuan sendiri, bukan sekedar menghafal. Selain itu, mahasiswa dapat menemukan dan menjelaskan kaitan suatu konsep dengan konsep lainnya. Pemahaman konsep dapat membantu mahasiswa untuk mengingat. Hal tersebut dikarenakan ide-ide matematika yang mahasiswa peroleh dengan 
mamahami saling berkaitan, sehingga mahasiswa lebih mudah untuk mengingat dan menggunakan, serta menyusunnya kembali saat lupa.

Menurut Bloom, pemahaman terdiri dari tiga kategori yaitu: penerjemahan (translation), penafsiran (interpretation), dan ekstrapolasi (extrapolation) (Syaiful Sagala. 2013):

\section{a. Penerjemahan (Translation)}

Translasi yaitu kemampuan untuk memahami suatu ide yangdiyatakan dengan cara lain dari pernyataan asli yang dikenalsebelumnya.Translasi menurut Jones merupakan sebuah aktivitas yangmelibatkan perubahan bentuk komunikasi. Sedangkan menurut Gusni (Gusni Satriawati: 2006) translasi merupakan pemahaman yang berkaitan dengan kemampuan dalam menerjemahkan kalimat dalam soal ke dalamkalimat lain, misalnya menyebutkan variabel-variabel yang diketahui danditanyakan.Sehingga kemampuan translasi (menerjemahkan) merupakanpengalihan dari bahasa konsep ke dalam bahasa sendiri, atau pengalihandari konsep abstrak ke suatu model yang lebih real yang dapat mempermudah orang untuk mempelajarinya.

Dalam kemampuan translasi, kata-kata maupun kalimat dalam soaldapat dialihkan menjadi bentuk lain seperti simbol, variabel, baganmaupun grafik dengan syarat pengalihan bentuk ini tidak boleh mengubahmakna sebenarnya. Proses translasi memerlukan pengetahuan dari materi sebelumnya, sehingga dapat mengintegrasikannya ke dalam konsepumum atau ide-ide yang relevan. Hal ini membutuhkan usaha yang kompleks seperti analisis atau aplikasi, maupun mengingat kembali pengetahuan yang sederhana.

b. Penafsiran (Interpretation)

Jones mengartikan interpretasi sebagai penyusunan kembali pengetahuan yang ada.Interpretasi proses penyusunan ulang suatu materi atau ide yang disajikan dalam suatu konfigurasi yang baru.Sedangkan menurut (Gusni Satriawati: 2006) interpretasi yaitu pemahaman yang berkaitan dengan kemampuan dalam menentukan konsepkonsep yang tepat untuk digunakan dalam menyelesaikan soal.Dengan kata lain, interpretasi merupakan proses penataan kembali materi atau pengetahuan yang ada yang disajikan ke dalam konsep baru dalam pikiran. Mahasiswa harus memahami hubungan antara ide-ide yang disajikan dan dapat mengidentifikasi ide-ide tersebut agar dapat menyusunnya dalam suatu konsep yang baru.

Jika dihubungkan dengan indikator pemahaman konsep menurut Skemp dan Peraturan Dirjen Dikdasmen No. 506/C/PP/2004, yang termasuk ke dalam kemampuan 
interpretasi antara lain kemampuan dalam menerapkan beberapa konsep perhitungan yang sederhana, menyajikan beberapa konsep yang disusun dalam berbagai bentuk representasi matematis, dan mengembangkan syarat perlu dan syarat cukup suatu konsep.

c. Ekstrapolasi (Extrapolation)

Ekstrapolasi menurut (Gusni Satriawati: 2006) adalah pemahaman yang berkaitan dengan kemampuan menerapakan konsep dalam perhitungan matematis untuk menyelesaikan soal. Ekstrapolasi merupakan kemampuan membuat prediksi atau perkiraan dari suatu masalah guna mendapatkan kemungkinan solusi.Dengan kata lain, kemampuan ekstrapolasi merupakan kemampuan untuk menentukan kelanjutan dari suatu temuan berdasarkan konsep yang ada dan menerapkannya dalam menyelesaikan soal. Kemampuan pemahaman jenis ekstrapolasi ini menuntut kemampuan intelektual yang lebih tinggi, seperti memikirkan tentang kemungkinan apa yang akan berlaku. Sehingga kemampuan ekstrapolasi dapat digunakan untuk menyelesaikan masalah.

\section{Strategi Pembelajaran Heuristik Vee}

Heuristik vee atau diagram vee diperkenalkan oleh D. Bob Gowin pada tahun 1977. Diagram vee digunakan sebagai alat bantu pengajaran yang didasari oleh teori belajar bermakna Ausubel (Ozgul Keles and Sibel Ozsoy, 2009). Diagram vee digunakan untuk membimbing mahasiswa dalam pengalaman laboratorium mereka, memudahkan berfikir reflektif dalam pembelajaran dan merencanakan penemuan mereka sendiri. Heuristikvee terdiri dari dua sisi, disebelah kiri merupakan aspek konseptual dan disebelah kanan aspek metodologi, kedua aspek ini secara langsung dihubungkan oleh kejadian atau objek yang diletakkan di titik (bagian bawah) bentuk vee, kejadian atau objek merupakan bagian terpenting untuk merumuskan penemuan. Bagian atas heuristik vee adalah pertanyaan fokus yang akan dicari penyelesaiannya dan berhubungan dengan kejadian atau objek yang ada pada ujung vee. Dari keterangan tersebut dapat diklasifikasikan secara umum komponen strategi pembelajaran heuristik vee yaitu sisi konseptual, kejadian atau objek, pertanyaan fokus, dan sisi metodologi. 
Bentuk modifikasi diagram vee ditunjukkan pada gambar berikut:

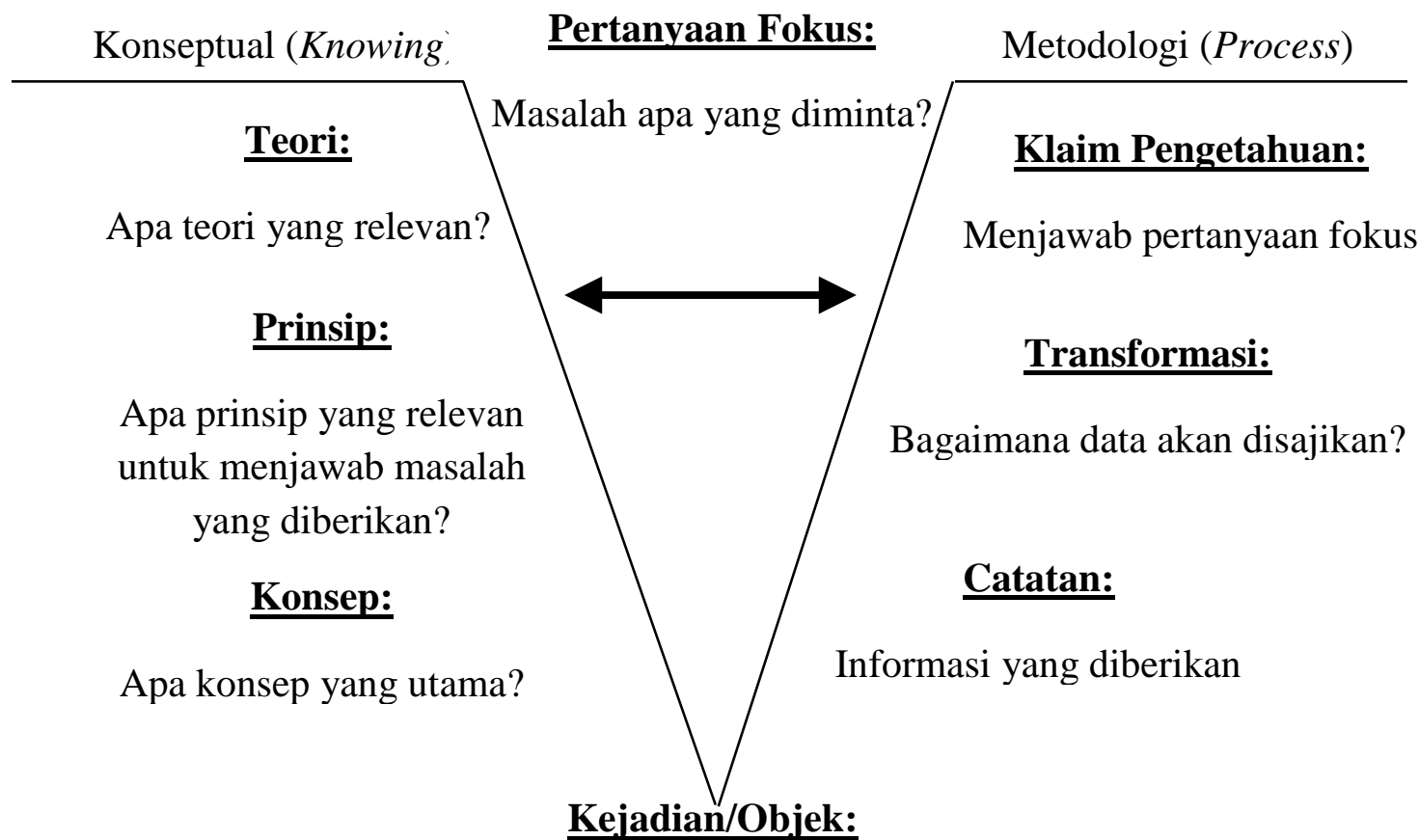

Pernyataan masalah yang diberikan

\section{Gambar 1. Bentuk Modifikasi Diagram Vee}

Penerapan strategi heuristik vee yang akan dilakukan dalam penelitian, menggunakan bentuk vee pengembangan dan perpaduan konsep yang dipaparkan Karoline AfamasagaFuata'i. Bentuk heuristik vee yang digunakan dalam penelitian, sebagai upaya untuk meningkatkan kemampuan pemahaman konsep matematika mahasiswa, ditampilkan dalam gambar dibawah ini: 


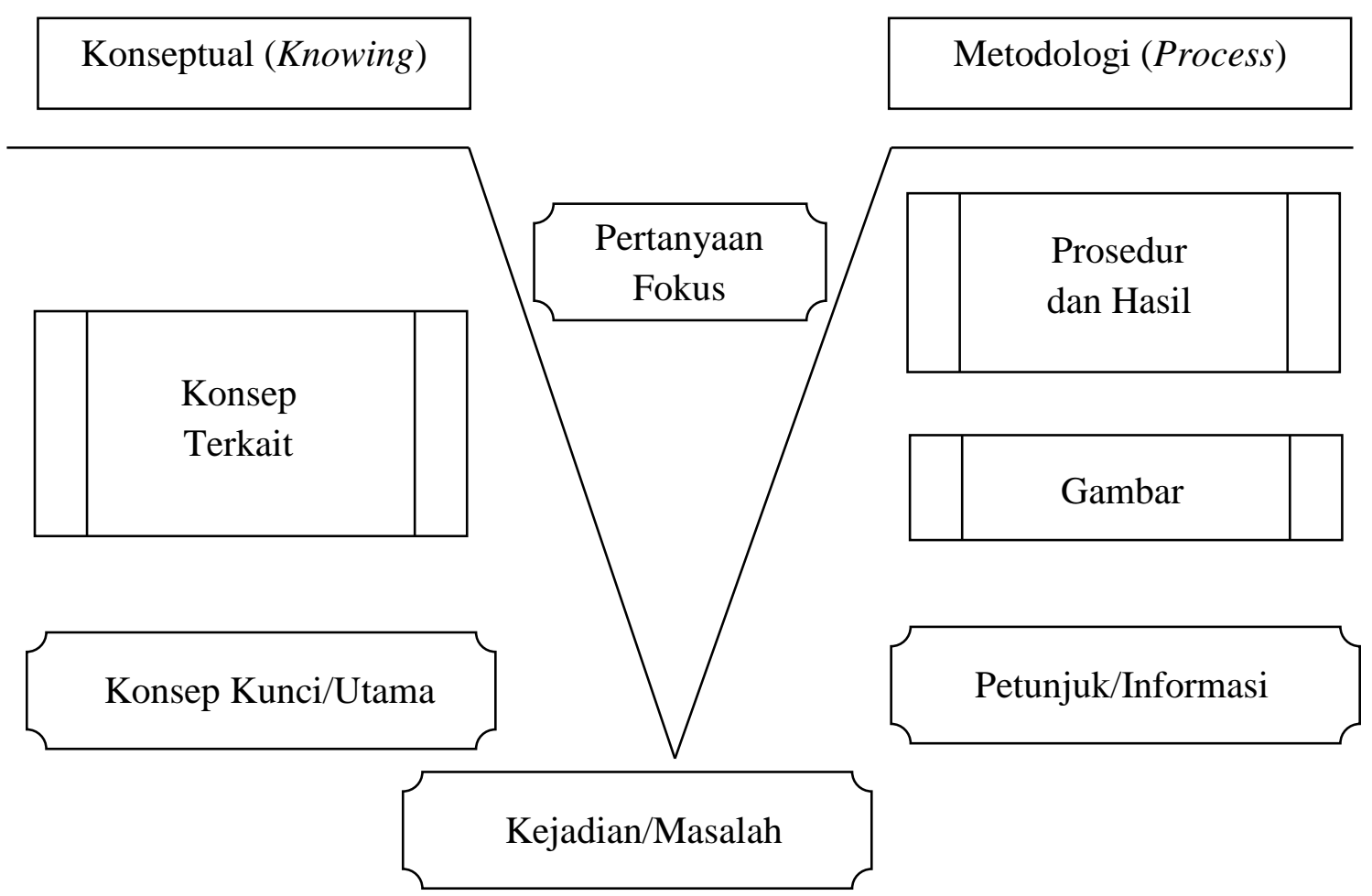

Gambar 2. Bentuk Heuristik Vee yang Digunakan dalam Penelitian

Adapun langkah-langkah dari proses pembelajaran 47ocus47tic vee adalah:

1) orientasi,memusatkan perhatian mahasiswa denganmenyebutkan beberapa kejadian dalam kehidupan sehari-hari yangberkaitan dengan materi pelajaran,

2) pengungkapan gagasan awal mahasiswa, meminta mahasiswa untuk melakukan penyelidikan melalui lembar kerja mahasiswa.Dosen tidak membenarkan atau menyalahkan konsep mahasiswa,

3) 47ocus penyelidikan, mengajukan permasalahanyang berkaitan dengan penyelidikan yang dilakukan dalam bentuk pertanyaan kunci,

4) mengonstruksi pengetahuan baru, mahasiswa melakukan penyelidikan atau eksperimen dari pertanyaan kunci yang diberikan oleh dosen, dan

5) evaluasi gagasan mahasiswa. Dengan demikian mahasiswa dapat melihat ketidaksesuaian gagasan yang dimiliki sebelumnya dan kemudian memperbaikinya. 
Berdasarkan teori dan penelitian yang sudah dilakukan sebelumnya, maka dapat dibuat kerangka berpikir seperti terlihat di bawah ini:

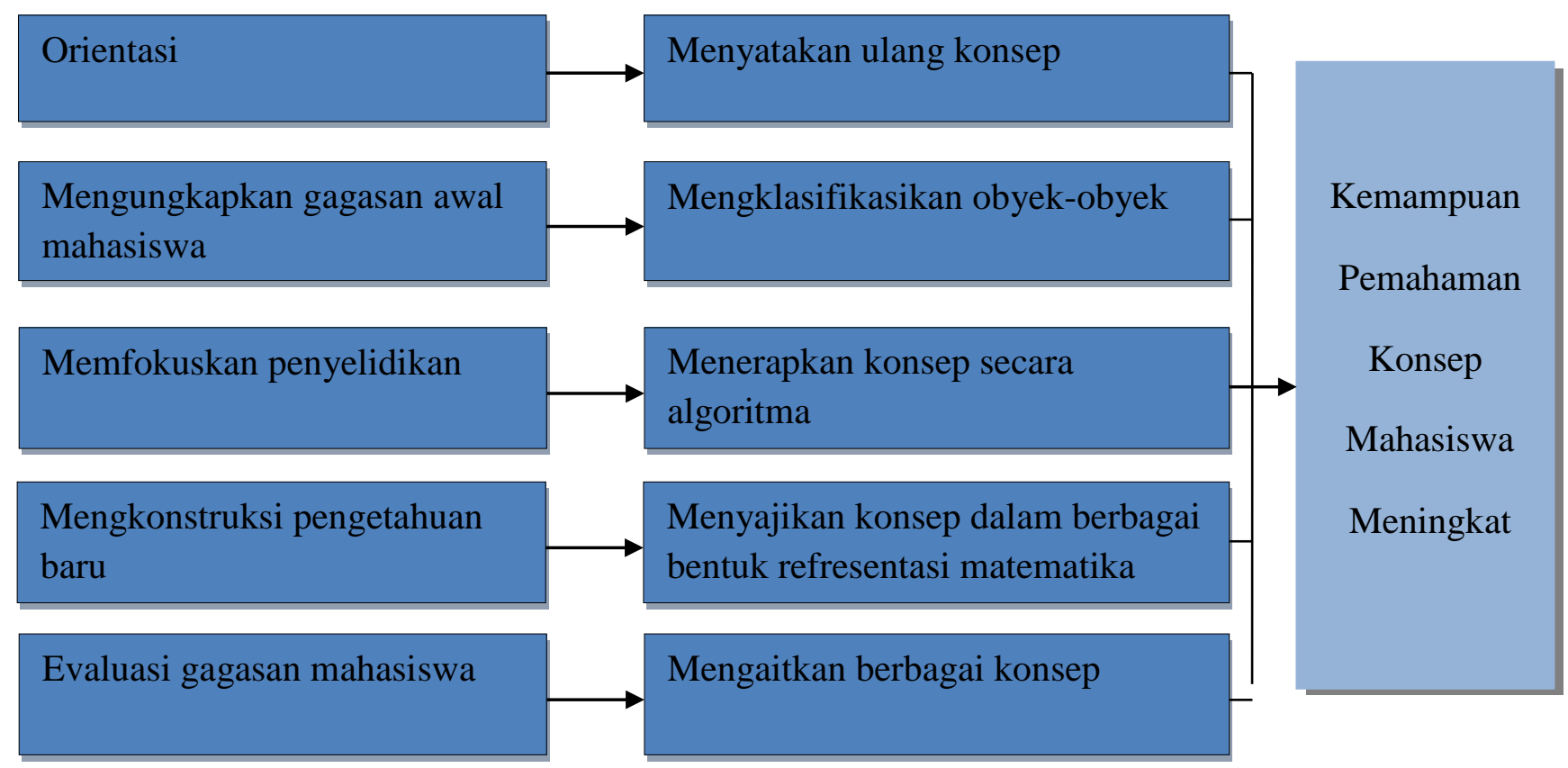

\section{Gambar 3. Kerangka Berpikir}

Diagram di atas menggambarkan bahwa tahapan dalam heuristic vee dapat berpengaruh terhadap kemampuan pemahaman konsep matematika mahasiswa.

Strategi pembelajaran heuristikvee adalah salah satu cara menyajikan bahan pembelajaran dalam bagan berbentuk huruf "V" dengan menuangkan pengetahuan awal yang kemudian dikaitkan dengan pengetahuan selanjutnya yang dituangkan secara lebih terperinci berupa pengonstruksian pengetahuan awal dengan pengetahuan barunya.

\section{METODE PENELITIAN}

Penelitian ini menggunakan jenis penelitian kuasi eksperimen. Desain eksperimen yang digunakan dalam penelitian ini adapun rancangan penelitian dengan menggunakan Randomized Control Group Post-test Only Design. Perlakuan khusus diberikan kepada kelas eksperimen dalam bentuk pemberian variabel bebas (Strategi Pembelajaran Heuristik Vee) untuk kemudian dilihat pengaruhnya pada variabel terikat (Kemampuan pemahaman konssep matematik mahasiswa).

Populasi penelitian ini adalah seluruh mahasiswa Semester V Tahun Akademik 
Diferensial. Teknik pengambilan sampel yang digunakan dalam penelitian ini adalah teknik Cluster Random Sampling yang mengambil 2 kelas dari seluruh kelas paralel yang ada. Kemudian dari 2 kelas tersebut diundi, kelas mana yang akan dijadikan kelas eksperimen dan kontrol. Untuk lebih jelas dapat dilihat pada tabel di bawah:

Tabel 1.

\begin{tabular}{|l|l|c|}
\hline Kelompok & Perlakuan & Test Akhir \\
\hline RE & $X_{1}$ (menggunakan heuristic vee) & $\mathrm{O}$ \\
\hline RK & $X_{2}$ (konvensional) & $\mathrm{O}$ \\
\hline
\end{tabular}

Data yang diperlukan dalam penelitian ini adalah skor kemampuan pemahaman konssep matematik mahasiswa dalam belajar matematika. Pengumpulan data dilakukan dengan menggunakan teknik tes, yaitu tes kemampuan pemahaman konsep matematik. Sebelum tes diberikan kepada mahasiswa, instrument tes harus melalui beberapa uji, antara lain:

\section{Uji Prasarat Analisis}

a. Uji Normalitas

Uji normalitas diperlukan untuk menguji apakah sebaran databerdistribusi normal atau tidak. Apabila sebaran data berdistribusinormal, maka dalam menguji kesamaan dua ratarata digunakan uji $t$. Tetapi apabila tidak berdistribusi normal maka tidak bisa menggunakan uji parametrik, tetapi menggunakan uji non-parametrik seperti uji MannWithney.

Untuk menguji normalitas digunakan dalam penelitian ini akan digunakan Uji Liliefors, dengan tahapan pengujian hipotesis sebagai berikut:

1) Perumusan hipotesis

$H_{0}$ : sampel berasal dari populasi berdistribusi normal

$H_{1}$ : sampel berasal dari populasi berdistribusi tidak normal

2) Statistik Hitung

$$
L_{0}=\max |F(Z)-S(Z)|
$$

3) Statistik Tabel

Derajat bebas $d b=n$, taraf nyata $\alpha=0.05$, sehingga diperoleh $L_{(0.05 ; n)}$

4) Membandingkan Statistik Hitung dengan Statistik Tabel 
$L_{0} \leq L_{(0.05, n)}$ maka terima $H_{0}$ artinya data berasal dari populasi yang berdistribusi normal.

$L_{0}>L_{(0.05, n)}$ maka tolak $H_{0}$ dan terima $H_{1}$ artinya data berasal dari populasi yang berdistribusi tidak normal.

5) Kesimpulan

b. Uji Homogenitas

Uji Homogenitas varians digunakan untuk menguji kesamaanvarians dari skor pada kedua kelompok sampel yang berasal daripopulasi yang sama (homogen). Apabila hasil pengujianmenunjukkan kesamaan varians maka untuk uji kesamaan dua rataratadigunakan uji $t$ (apabila berdistribusi normal) dan digunakanvarians gabungan. Apabila hasil pengujian menunjukkan tidakhomogen maka digunakan uji $t$ tanpa varians gabungan. Untukmenguji homogenitas tersebut digunakan rumus statistik uji $F$ (Fisher)sebagai berikut:

1) Perumusan hipotesis

$$
\begin{aligned}
& H_{0}: \sigma_{E}^{2}=\sigma_{K}^{2} \\
& H_{1}: \sigma_{E}^{2} \neq \sigma_{K}^{2}
\end{aligned}
$$

2) Statistik Hitung

$$
F_{\text {hit }}=\frac{\text { varians terbesar }}{\text { varians terkecil }}=\frac{s_{1}^{2}}{s_{2}^{2}}, s^{2}=\frac{n \sum X^{2}-\left(\sum X\right)^{2}}{n(n-1)}
$$

3) Statistik Tabel

Derajat bebas $d b_{1}=n_{1}-1, d b_{2}=n_{2}-1$, taraf nyata $\alpha=0.05$, sehingga diperoleh $F_{\left(d b_{1} ; d b_{2} ; \alpha\right)}$

4) Membandingkan Statistik Hitung dengan Statistik Tabel

$F_{h i t} \leq F_{\left(d b_{1} ; d b_{2} ; \alpha\right)}$ maka terima $H_{0}$ (varians kedua sampel homogen)

$F_{\text {hit }}>F_{\left(d b_{1} ; d b_{2} ; \alpha\right)}$ maka tolak $H_{0}$ dan terima $H_{1}$ (varians kedua sampel tidak homogen).

5) Kesimpulan

\section{Uji Hipotesis}

a. Jika $\sigma_{E}^{2}=\sigma_{K}^{2}$ 


$$
\begin{aligned}
& t_{h i t}=\frac{\bar{X}_{E}-\bar{X}_{K}}{s_{g} \sqrt{\frac{1}{n_{E}}+\frac{1}{n_{K}}}}, \quad d b=n_{E}+n_{K}-2 \\
& s_{g}^{2}=\frac{\left(n_{E}-1\right) s_{E}^{2}+\left(n_{K}-1\right) s_{K}^{2}}{n_{E}+n_{K}-2}
\end{aligned}
$$

b. $\quad \mathrm{Jika} \sigma_{E}^{2} \neq \sigma_{K}^{2}$

$$
t_{\text {hit }}=\frac{\bar{X}_{E}-\bar{X}_{K}}{\sqrt{\frac{s_{E}^{2}}{n_{E}}+\frac{s_{K}^{2}}{n_{K}}}}, \quad d b=\frac{\left(\frac{s_{E}^{2}}{n_{E}}+\frac{s_{K}^{2}}{n_{K}}\right)^{2}}{\frac{\left(\frac{s_{E}^{2}}{n_{E}}\right)^{2}}{n_{E}-1}+\frac{\left(\frac{s_{K}^{2}}{n_{K}}\right)^{2}}{n_{K}-1}}
$$

c. Jika tidak Normal

$$
\begin{aligned}
& U=n_{1} n_{2}+\frac{n_{1}\left(n_{1}+1\right)}{2}-K_{1} \\
& U: \text { Statisti Mann-Whitney } \\
& K_{1}: \text { Jumlah ranking pada sampel dengan ukuran } n \text { terkecil } n=\min \left(n_{1}, n_{2}\right)
\end{aligned}
$$

Untuk sampel yang lebih besaar dari 20, maka distribusi $U$ dapat didekati dengan distribusi normal sebagai berikut:

$$
\begin{aligned}
& Z=\frac{U-\mu_{U}}{\sigma_{U}} \\
& \mu_{U}=\frac{n_{1} n_{2}}{2} \\
& \sigma_{U}=\sqrt{\frac{n_{1} n_{2}\left(n_{1}+n_{2}+1\right)}{12}}
\end{aligned}
$$

Hipotesis Statistik:

$$
\begin{aligned}
& H_{0}: \mu_{E} \leq \mu_{K} \\
& H_{1}: \mu_{E}>\mu_{K}
\end{aligned}
$$

\section{HASIL DAN PEMBAHASAN}

Ada beberapa nilai statistik deskriptif diantaranya ukuran pemusatan, dan ukuran penyebaran, ukuran pemusatan terdiri dari rata-rata, median, dan modus. Sedangkan ukuran penyebaran terdiri dari: varians/ragam, standar deviasi dan rang. Hasil perhitungan statistik deskriptif dari kedua kelas dapat dilihat dalam Tabel di bawah ini: 
Tabel 2. Hasil Perhitungan Statistik Deskriptif

\begin{tabular}{|l|l|r|r|}
\hline No & Ukuran Statistik & \multicolumn{1}{|c|}{ Eksperimen } & \multicolumn{1}{|c|}{ Kontrol } \\
\hline 1 & Jumlah sampel & 28 & 27 \\
\hline 2 & Range & 41 & 36 \\
\hline 3 & Rata-rata $(\bar{X})$ & 83,96 & 78,30 \\
\hline 4 & Varians & 150,92 & 87,293 \\
\hline 5 & Standar Deviasi & 12,29 & 9,343 \\
\hline 6 & Maksimum & 99 & 94 \\
\hline 7 & Minimum & 58 & 58 \\
\hline 8 & Kurtosis & 0,795 & $-0,096$ \\
\hline 9 & Skewness & $-0,996$ & $-0,568$ \\
\hline
\end{tabular}

Dari hasil perbandingan kedua kelas terlihat bahwa rata-rata kemampuan pemahaman konsep mahasiswa pada kelas eksperimen $(83,96)$ lebih tinggi dibandingkan kelas kontrol $(78,30)$. Ini artinya rata-rata kemampuan pemahaman konsep mahasiswa pada kelas yang menggunakan pembelajaran heuristic vee lebih tinggi dibandingkan rata-rata kemampuan pemahaman konsep mahasiswa pada kelas kontrol. Nilai tertinggi juga berada di kelas eksperimen -pada kelas eksperimen sebesar 99 sedangkan pada kelas konttrol sebesar 94, sedangkan nilai terendah pada kedua kelas eksperimen dan kontrol sama yaitu 53.

Berdasarkan nilai keragamannya terlihat keragaman pada kelaas eksperimen pada kelas eksperimen lebih besar dibandingkan dengan kelas kontrol, ini artinya perbedaan kemampuan pemahaman konsep antar mahasiswa pada kelas eksperimen lebih tinggi dibandingkan perbedaan kemampuan pemahaman konsep antar mahasiswa pada kelas kontrol, ini juga terlihat pada berdasarkan rentangnya pada kelas eksperimen sebesar 41 sedangkan kelas kontrol sebesar 36.

a. Uji Normalitas

Uji normalitas digunakan untuk mengetahui apakah data pada kelas eksperimen yang pada pembelajarannya menggunakan heuristic vee dan data pada kelas kontrol berasal dari populasi yang berdistribusi normal atau tidak.

Tabel 3. Uji Normalitas Kelas Eksperimen

\begin{tabular}{|l|c|c|c|}
\hline No. & Statistik & Kriteria & Kesimpulan \\
\hline 1 & $L_{0}=0,1105$ & \multirow{2}{*}{$L_{0}(0,1105)<L_{t a b}(0,161)$} & Terima $H_{0}$ \\
\hline 2 & $L_{t a b}=0,161$ & & \\
\hline
\end{tabular}


Berdasarkan hasil perhitungan diperoleh statistik hitung dan statistik tabel, sehingga:

Karena nilai statistik hitung lebih kecil dari statistik tabel maka $H_{0}$ diterima. Kesimpulan dari uji normalitaas data adalah: Sampel berasal dari polulasi berdistribusi normal, atau data kemampuan pemahaman konsep pada kelas eskperimen mempunyai distribusi yang normal.

Tabel 4. Uji Normalitas Kelas Kontrol

\begin{tabular}{|c|c|c|c|}
\hline No. & Statistik & Kriteria & Kesimpulan \\
\hline 1 & $L_{0}=0,0865$ & \multirow{2}{*}{$L_{0}(0,0856)<L_{t a b}(0,161)$} & Terima $H_{0}$ \\
\hline 2 & $L_{t a b}=0,161$ & & \\
\hline
\end{tabular}

Karena nilai statistik hitung lebih kecil dari statistik tabel maka $H_{0}$ diterima. Kesimpulan dari uji normalitaas data adalah: Sampel berasal dari polulasi berdistribusi normal, atau data kemampuan pemahaman konsep pada kelas eskperimen mempunyai distribusi yang normal.

Tabel 5. Uji Homogenitas

\begin{tabular}{lrr}
\hline & Eksperimen & Kontrol \\
\hline Mean & 83,964 & 78,296 \\
Variance & 150,925 & 87,293 \\
Observations & 28 & 27 \\
Df & 27 & 26 \\
F & 1,729 & \\
P $(\mathrm{F}<=f)$ one-tail & 0,083 & \\
F Critical one-tail & 1,921 & \\
\hline
\end{tabular}

Kesimpulan : Kedua sampel mempunyai varians yang homogen.

Tabel 6. Pengujian Beda Rata-Rata

\begin{tabular}{lrr}
\hline & Eksperimen & Kontrol \\
\hline Mean & 83,964 & 78,296 \\
Variance & 150,925 & 87,293 \\
Observations & 28 & 27 \\
Pooled Variance & 119,709 & \\
Hypothesized Mean & & \\
Difference & 0 & \\
Df & 53 & \\
t Stat & 1,921 & \\
P $(\mathrm{T}<=t)$ one-tail & 0,030 & \\
t Critical one-tail & 1,674 & \\
& & \\
\hline
\end{tabular}


Kesimpulan

Kemampuan pemahaman konsep mahasiswa yang menggunakan strategi heuristic vee lebih tinggi dari pada kemampuan pemahaman konsep mahasiswa yang menggunakan strategi konvensional.

\section{Pembahasan}

Berdasarkan hasil pengujian di atas maka dapat disimpulkan bahwa kemampuan pemahaman konssep matematika di kelas eksperimen yang dalam pembelajarannya menggunakan strategi heuristic vee sangat baik. Hal ini dapat diketahui secara kasat mata dari nilai rata-ratanya yang lebih tinggi dibandingkan pada kelas kontrol.

Ketika menjawab soal pada ujian akhir mahasiswa pada kelas eksperimen juga sudah bisa mengaitkan dengan materi/matakuliah yang lain, misalkan untuk menjawab soal nomor satu beberapa mahasiswa untuk mencari jawaban ada yang menggunakan metode eliminasi dan substitusi dan juga yang menggunakan metode matriks. Materi ini mereka peroleh pada matakuliah program linier. Untuk lebih jelasnya dapat kita lihat pada gambar di bawah:

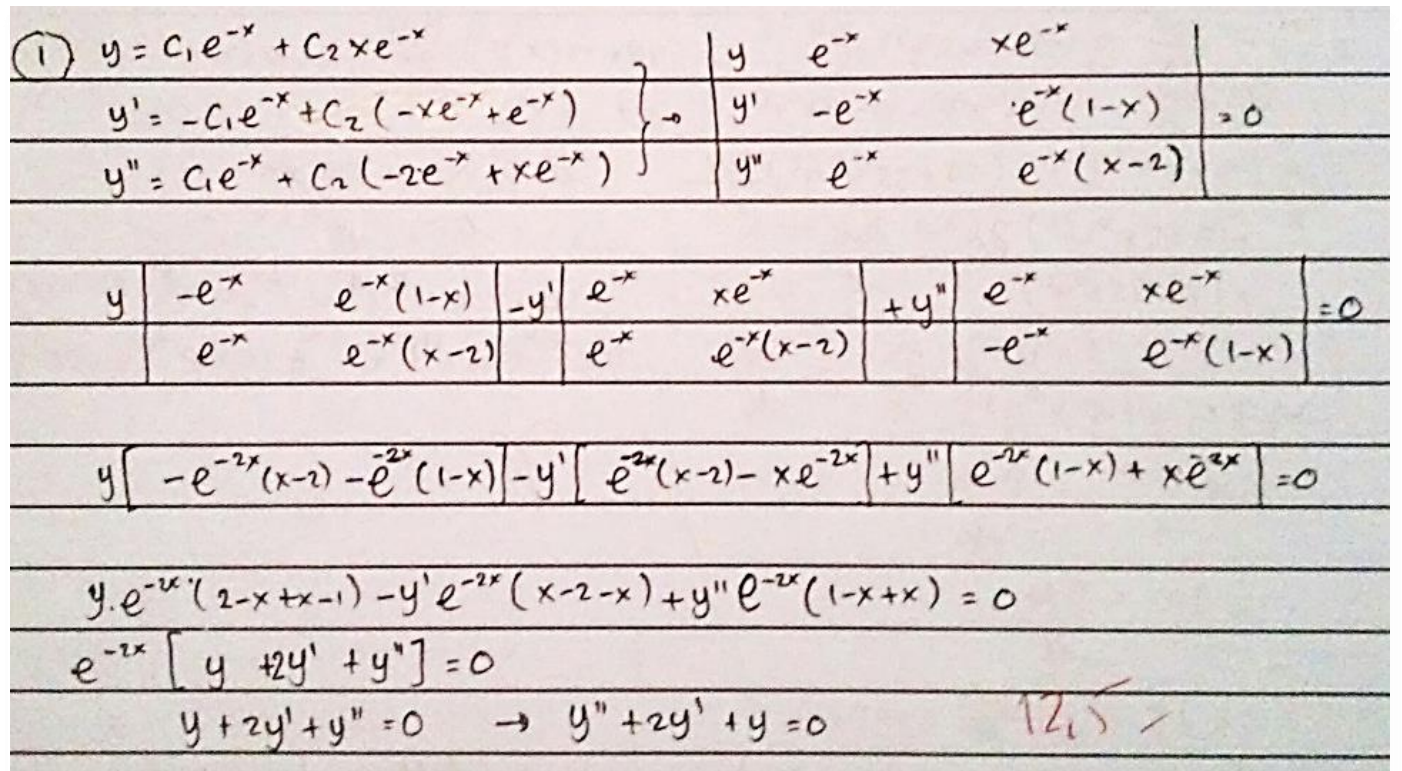

\section{Gambar 4. Jawaban Mahasiswa dengan Metode Matriks}

Gambar di atas memperlihatkan jawaban mahasiswa yang menggunakan metode matriks untuk mencari bentuk persamaan diferensial jika solusi persamaan diferensialnya diketahui. Metode ini sebenarnya dalam kasus tertentu lebih mudah dibandingkan metode eliminasi-substitusi, karena pengerjaannya lebih sederhana. Pada gambar di bawah diperlihatkan cara mencari bentuk persamaan diferensial jika solusinya diketahui dengan 
menggunakan metode eliminsai dan substitusi. Dengan menggunakan metode ini tahapannya relatif lebih panjang dan bisa menimbulkan banyak kesalahan dalam proses pengerjaannya. Walaupun pada kenyataannya dari jawaban mahasiswa lebih banyak yang menggunakan metode ini dibandingkan menggunakan metode matriks, hal ini bisa disebabkan karena meode eliminasi dan substitusi lebih familier dibandingkan metode matriks. Untuk lebih jelasnya penyelesaian soal nomor satu dengan menggunakan metode eliminasi dan substitusi dapat dilihat pada gambar di bawah.

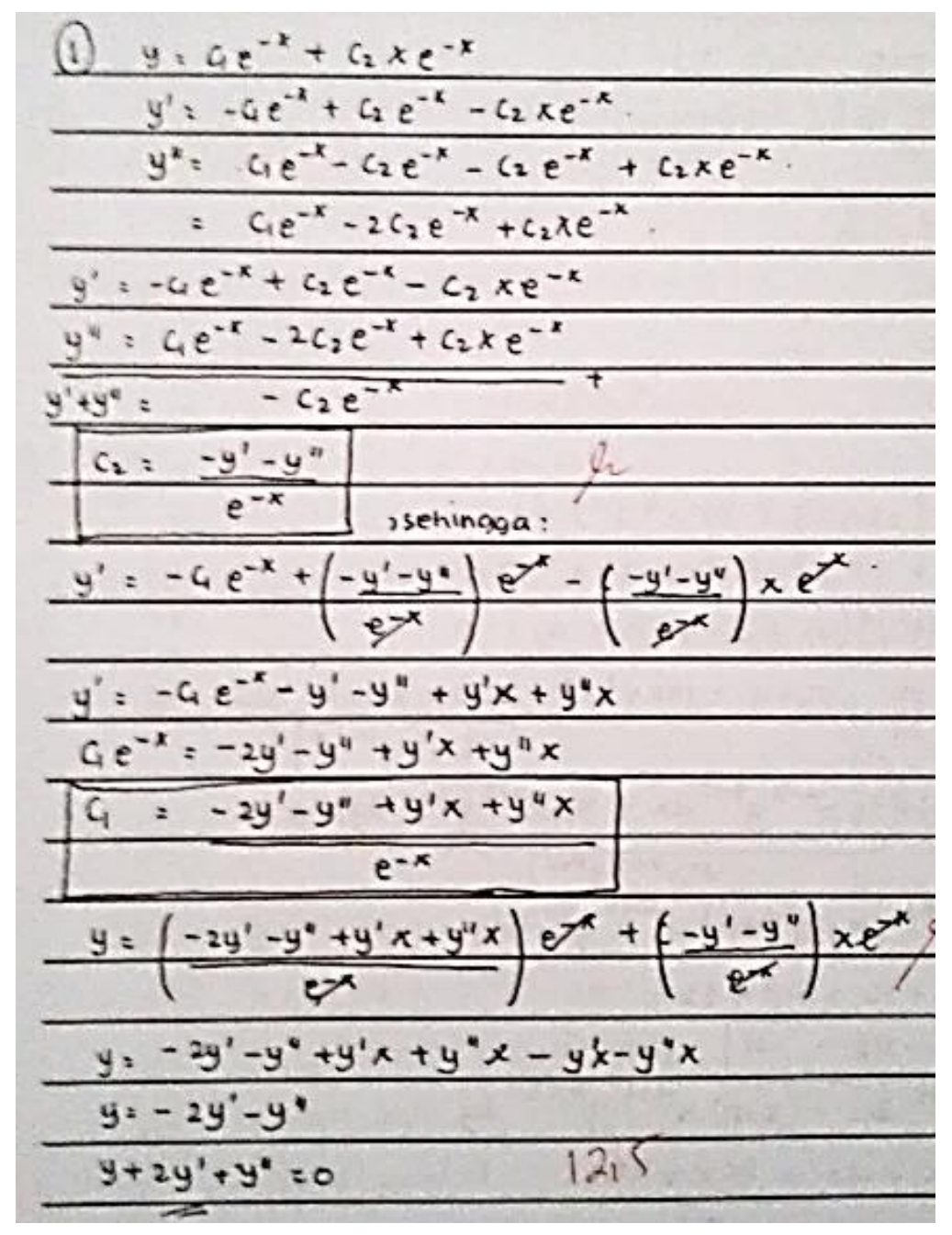

\section{Gambar 5. Jawaban Mahasiswa dengan Metode Eliminasi dan Substitusi}

Mirip dengan hasil penelitian yang dilakukan oleh Calais yang menunjukkan bahwa diagram vee (sebuah pembelajaran heuristik) adalah strategi yang ideal untuk meningkatkan kemampuan penemuan siswa dalam penyelidikan sains dan matematika. Pemahaman konsep juga bisa diperoleh dengan cara penemuan dimana mahasiswa mengkonstruksi pemahamannya sendiri sehingga pemahaman yang diperoleh bisa lebih lama karena masuk dalam long term memory. 


\section{SIMPULAN DAN SARAN}

Berdasarkan hasil penelitian dan pembahasan diperoleh beberapa kesimpulan sebagai berikut:

a. Kemampuan pemahaman konsep matematik mahasiswa yang diajarkan dengan dengan strategi pembelajaran heuristic vee lebih baik daripada pemahaman konsep matematik mahasiswa yang diajarkan dengan strategi pembelajaran konvensional. Hal ini bisa dilihat dari rata-rata kedua kelompok sampel pada kelasa eksperimen rata-rata kemampuan pemahaman konsep matematikanya 83,96, sedangkan untuk kelas kontrol diperoleh rata-rata kemampuan pemahaman konsepnya sebesar 78,3.

b. Kemampuan pemahaman konsep matematik mahasiswa yang menggunakan strategi pembelajaran heuristik vee lebih tinggi daripada kemampuan konsep matematik mahasiswa yang diajarkan menggunakan pembelajaran konvensional $\left(t_{\text {hitung }}=\right.$ 1,96 $>t_{\text {tabel }}=1,66$ ). Dengan demikian $H_{0}$ ditolak dan $H_{1}$ diterima. Dengan demikian dapat disimpulkan bahwa pemahaman konsep matematik mahasiswa yang menggunakan strategi pembelajaran heuristik vee lebih baik dibandingkan dengan strategi pembelajaran konvensional.

Berdasarkan temuan yang penulis temukan dalam penelitian ini, ada beberapa saran, diantaranya:

a. Berdasarkan hasil penelitian bahwa strategi pembelajaran heuristik vee mampu meningkatkan pemahaman konsep matematik mahasiswa, sehingga pembelajaran tersebut dapat menjadi salah satu pilihan pembelajaran matematika yang dapat diterapkan oleh dosen.

b. Fakultas harus bisa memfasilitasi para dosen yang akan mengujicobakan strategi pembelajaran di kelas.

c. Penelitian berikutnya mungkin dapat meneliti indikator kemampuan matematik yang lainnya yang belum diteliti dalam penelitian ini.

\section{DAFTAR PUSTAKA}

Dahar, R W. ( ) Teori-teori Belajar dan Pembelajaran. Jakarta : Erlangga.

Rosyada, Dede. (2004). Paradigma Pendidikan Demokratis. Jakarta: Kencana.

Gerald J. Calais. (2009). "The Vee Diagram as a Problem Solving Strategy: Content Area Reading/Writing Implication". National Forum Teacher Education Journal. Vol 19 (3).

Idris, Noraini. (2009). Enhancing Students Understanding In Calculus Trough Writing. Malaysia: International Electronic Jurnal of Mathematics Education. 
Kadir. (2010). Statistika untuk Penelitian Ilmu-Ilmu Sosial. Jakarta: PT Rosemata Sempura.

Kilpatrick, J., Swafford, J., dan Findell, B. (Eds.). (2001). Adding it Up: Helping Children Learn Mathematics. Washington, DC: National Academy Press.

Ni Md. Okty Purwani dkk (2014). "Pengaruh Model Pembelajaran Heuristik Vee terhadap Pemahaman Konsep IPA Siswa Kelas V SD Gugus II Kecamatan Mendoyo". Mimbar $P G S D$ : Universitas Pendidikan Ganesha. Vol. 2 (1) [e-Journal]

Ozgul Keles and Sibel Ozsoy (2009). "Pre-service teachers' attitudes toward use of Vee diagrams in general physics laboratory". Internasional Electronic Journal of Elementary Education. Vol 1, (3), Juni.

Suhenda (2007). Pengembangan Kurikulum dan Pembelajaran Matematika. Jakarta: Universitas Terbuka.

Suherman, E. dkk. (2003). Strategi Pembelajaran Matematika Kontemporer. Bandung: UPI

Suherman, E. (2003). Evaluasi Pembelajaran Matematika. Bandung: UPI

Wardhani, Sri (2008). Analisis SI dan SKL Mata Pelajaran Matematika SMP/MTs untuk Optimalisasi Tujuan Mata Pelajaran Matematika. Yogyakarta: Pusat Pengembangan dan Pemberdayaan Pendidik dan Tenaga Kependidikan Matematika. 